\title{
Crouzon Syndrome: a case report
}

\author{
David Reid", Stuart Morrison \\ From Society of Chiropodists and Podiatrists Annual Conference 2010 \\ Bournemouth, UK. 21-23 October 2010
}

Crouzon Syndrome is a rare genetic disorder resulting from a mutation of the Fibroblast Growth Factor Receptor 2 Gene. The main presenting feature of this syndrome is craniofacial synostosis but multiple physical dysmorphic features have been reported. There is a dearth of literature detailing the presentation of this syndrome in the foot and lower limb. Therefore, this case report will describe the clinical characteristics of a 22 year old female referred for podiatric assessment. It will also explore the possible treatment options considered for this case.

Published: 20 December 2010

- Convenient online submission

- Thorough peer review

- No space constraints or color figure charges

- Immediate publication on acceptance

- Inclusion in PubMed, CAS, Scopus and Google Scholar

- Research which is freely available for redistribution 